\title{
Bilateral simultaneous anterior obturator dislocation of the hip by an unusual mechanism - a case report
}

\author{
Olağandışı bir mekanizmayla çift taraflı, eşzamanlı anterior obturator kalça çıkığı: \\ Olgu sunumu
}

\author{
Asif SULTAN, ${ }^{1}$ Tahir Ahmad DAR, ${ }^{1}$ Mohd Iqbal WANI, ${ }^{1}$ Mubashir Maqbool WANI, ${ }^{1}$ Samina SHAFI ${ }^{2}$
}

A case of bilateral simultaneous anterior dislocation of the hip in a 30-year-old female is presented herein. The patient was managed conservatively. Follow-up at two years showed excellent results with no signs of avascular necrosis. The cause and mechanism of injury are discussed, which are different from those of previously reported cases.

Key Words: Avascular necrosis; bilateral anterior dislocation of the hip; traumatic; mechanism of injury.

Bilateral anterior dislocation of the hip is very rare. Only a few cases have been reported previously. ${ }^{[1-12]}$ The majority of these cases were either due to road traffic accidents ${ }^{[2-4,7-9]}$ or high- impact trauma. ${ }^{[1,5,11,12]}$

We describe a case involving simultaneous bilateral traumatic anterior obturator type hip dislocation with a distinctly different cause and mechanism of injury.

\section{CASE REPORT}

A 30-year-old female presented to our emergency department with a history of slipping in the bathroom. Both her legs had extended outwards, and her buttocks had hit the bathroom floor. She immediately experienced severe pain in both hips, which she was unable to move. She arrived in the emergency department within two hours of the injury. On physical examination, both hips were in flexion, abduction and external rotation. Passive and active movements were not possible in either hip. There were no neurovascular deficits in either of her lower limbs. There were no associated injuries, and she was hemodynamically stable.
Otuz yaşında bir kadın hasta çift taraflı ve eşzamanlı olarak her iki kalça ekleminde anterior dislokasyonla başvurdu. Hasta konservatif yolla tedavi edildi. İki yıllık takip avasküler nekroz belirtileri olmaksızın mükemmel sonuçlar alındığını gösterdi. Yaralanmanın önceden bildirilen olgulardan farklı olan nedeni ve mekanizması tartışıldı.

Anahtar Sözcükler: Avasküler nekroz; bilateral anterior kalça ç1kı ̆̆1; travmatik; yaralanma mekanizması.
Radiographs of the pelvis were taken, which showed bilateral anterior dislocation of the hip joints into the obturator foramen. No associated fracture was seen (Fig. 1). The dislocations were immediately reduced under general anesthesia without any difficulty by traction in the line of the deformity followed by gentle adduction and internal rotation, with the pelvis stabilized by an assistant. Both hips were clinically stable after the closed reduction, with no restriction of range of motion. Post-reduction radiographs showed concentric and congruent reduction of both hips.

Skin traction (below knee) was applied on both sides and the patient was kept on bed rest for three weeks with continuous traction, followed by a further three weeks on non-weight-bearing. Weight-bearing was started six weeks after the injury, with the patient returning to full activities at three months.

At the two-year follow-up, the patient was painfree with full range of motion of both hips and had no radiographic signs of avascular necrosis of the femoral head (Fig. 2). 


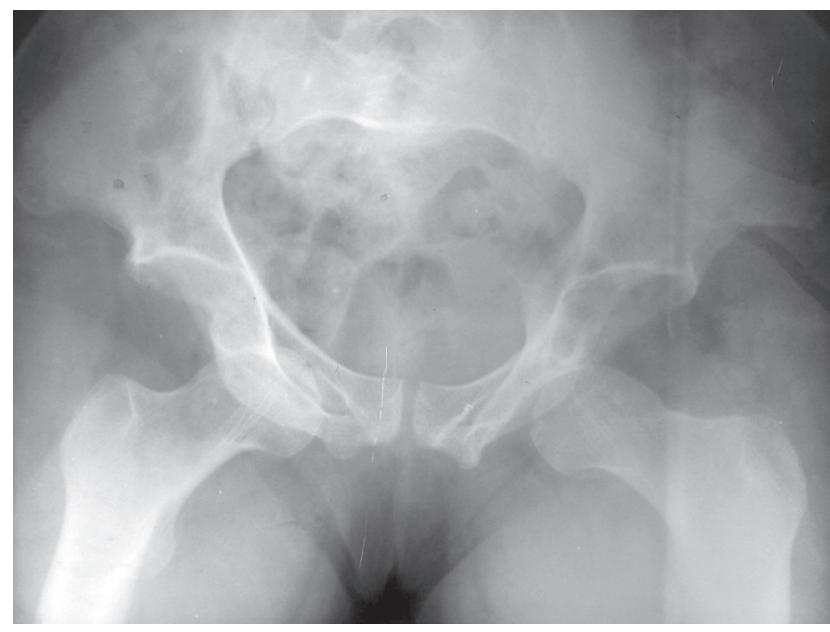

Fig. 1. Anteroposterior radiograph of the pelvis showing bilateral anterior dislocation of the hip into the obturator foramen.

\section{DISCUSSION}

Dislocations of the hip are classified as anterior or posterior according to the position of the femoral head. Anterior dislocations have been further subclassified as superior, inferior, and luxatio erecta of hip, obturator and pubic type. ${ }^{[13,14]}$ Anterior dislocations of the hip are less common than posterior type, comprising $10-15 \%$ of all hip dislocations ${ }^{[15]}$ and inferior dislocation is the most common type of anterior dislocation, comprising more than $70 \%$ of anterior dislocations. ${ }^{[13]}$ The lower incidence of anterior dislocation may be due in part to the strong anterior capsule and Y-shaped ligament of Bigelow, which is a strong disincentive to anterior dislocation. ${ }^{[13]}$

Superior dislocation occurs when the hip is forced into abduction and external rotation with extension of the hip. Inferior dislocation occurs when the hip is forced into abduction and external rotation with flexion of the hip. Obturator-type dislocation occurs in forced abduction, external rotation and flexion of the hip, and the force applied in this position seems to be the most likely mechanism. ${ }^{[7,13]}$ Road traffic accidents were the cause of bilateral anterior dislocations of the hip in the majority of cases ${ }^{[2-4,7-9]}$ with dashboard impact, where sudden deceleration created the dislocating force. Other cases reported also had high-energy trauma in the forms of a collapsed roof falling on to the lower back, ${ }^{[1]}$ during electroconvulsive therapy, ${ }^{[5]}$ by a collapsed floor on to a lower flat, ${ }^{[11]}$ and by a striking blow from a heavy object (weighing $600 \mathrm{lbs}$ ) over the buttocks area, ${ }^{[12]}$ with both lower extremities fixed and both hips flexed, abducted and externally rotated.

Our patient had slipped in the bathroom with both her lower limbs going into wide abduction, with external rotation and flexion at the hips and with her but-

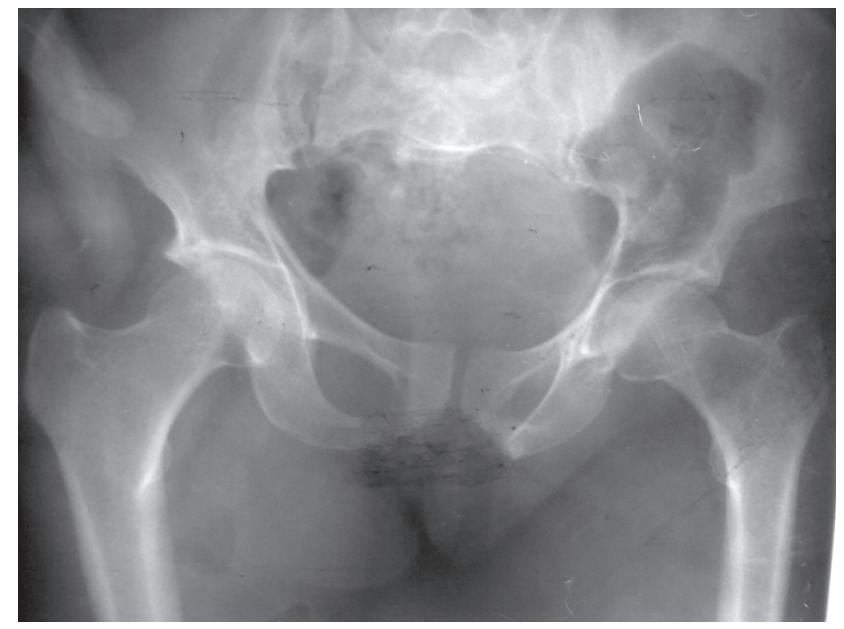

Fig. 2. At the two-year follow-up, anteroposterior radiograph of the pelvis showing both hip joints with no avascular changes.

tocks hitting the floor and acting as a force in this hip position, causing both hips to be dislocated anteriorly and inferiorly into the obturator foramen. To the best of our knowledge, this cause/mechanism of injury has not been reported previously.

All the cases of bilateral anterior dislocation of the hips reported previously were reduced by closed methods, including our case, except for one neglected case. ${ }^{[1]}$ Dislocation of the hip is an orthopedic emergency. Early reduction of the dislocated joint is necessary to reduce the risk of avascular necrosis, which is seen in $0-5 \%$ if the hip is reduced in less than six hours after the injury versus in $50 \%$ if the hip is reduced more than six hours after the injury. ${ }^{[13,14]}$ In our case, the reduction was done within three hours of the injury. Prompt and gentle reduction under suitable anesthesia is very important to avoid complications, and for all hip dislocations, the goal is to obtain a congruent and stable hip.

Consent: The report has been published after obtaining the due consent of the patient.

\section{REFERENCES}

1. Aggarwal ND, Singh H. Unreduced anterior dislocation of the hip. Report of seven cases. J Bone Joint Surg Br 1967;49:288-92.

2. M'Bamali EI. Unusual traumatic anterior dislocation of the hip. Injury 1975;6:220-4.

3. Gibbs A. Bilateral obturator dislocation of the hip joint. Injury 1980;12:250-1.

4. Zamani MH, Saltzman DI. Bilateral traumatic anterior dislocation of the hip: case report. Clin Orthop Relat Res 1981:203-6.

5. Sethi TS, Mam MK, Kakroo RK. Bilateral traumatic anterior dislocation of the hip. J Trauma 1987;27:573-4.

6. Tezcan R, Erginer R, Babacan M. Bilateral traumatic anterior dislocation of the hip: brief report. J Bone Joint Surg Br 1988;70:148-9. 
7. Endo S, Hoshi S, Takayama H, Kan E. Traumatic bilateral obturator dislocation of the hip joint. Injury 1991;22:232-3.

8. Terahata N, Matsui H, Makiyama N. Bilateral anterior dislocation of the hips. A case report. Int Orthop 1996;20:125-6.

9. Sneath RJ, Morgan NP. Bilateral traumatic anterior dislocation of the hip joint. J Accid Emerg Med 1997;14:391.

10. Duygulu F, Karaoglu S, Kabak S, Karahan OI. Bilateral obturator dislocation of the hip. Arch Orthop Trauma Surg 2003;123:36-8.

11. Domingo A, Segur JM, Saz L, Ramiro SG.Unusual traumatic anterior bilateral hip dislocation. J Orthop Surg Traumatol 2008; 18:475-8.
12. Chung KJ, Eom SW, Noh KC, Kim HK, Hwang JH, Yoon HS, et al. Bilateral traumatic anterior dislocation of the hip with an unstable lumbar burst fracture. Clin Orthop Surg 2009;1:114-7.

13. Phillips AM, Konchwalla A. The pathologic features and mechanism of traumatic dislocation of the hip. Clin Orthop Relat Res 2000;377:7-10.

14. Epstein HC. Traumatic dislocations of the hip. Clin Orthop Relat Res 1973;92:116-42.

15. DeLee JC, Evans JA, Thomas J. Anterior dislocation of the hip and associated femoral-head fractures. J Bone Joint Surg Am 1980;62:960-4. 